\title{
O-diphenoloxidase concentrations in leprosy
}

\author{
K REZA，S TALIB， S K IMAM
}

British Medical fournal, 1979, 2, 900-901

\section{Summary and conclusions}

O-diphenoloxidase activity was studied in 15 patients with lepromatous leprosy, 15 with tuberculoid leprosy, and 15 controls. O-diphenoloxidase isolated from skin and serum samples of patients with lepromatous leprosy had the specificity of a bacterially derived enzyme and not that of a mammalian-derived enzyme. Only the patients who had had lepromatous leprosy for over two years showed enzyme activity in serum, though all showed it in skin tissue.

O-diphenoloxidase activity in serum may be a useful diagnostic marker of lepromatous leprosy.

\section{Introduction}

O-diphenoloxidase (O-Diphenol: $\mathrm{O}_{2}$ oxidoreductase ECI 10:31) is widely distributed in plants and animals. Prabhakaran ${ }^{1}$ reported the presence of phenoloxidase in Mycobacterium leprae obtained from the spleen at necropsy, but there have been no reports on the level of O-diphenoloxidase in the serum of patients with leprosy. We describe here the results of our study on levels of $\mathrm{O}$-diphenoloxidase in serum and skin tissue from patients suffering from leprosy.

\section{Patients and methods}

Forty-five subjects were studied- 15 healthy people, 15 patients with tuberculoid leprosy, and 15 with lepromatous leprosy. The diagnoses were made on the basis of clinical findings, smear examinations, histological features, and the lepromine test.

J N Medical College, Aligarh Moslem University, Aligarh, India K REZA, MB, BS, clinical pathologist

$S$ TALIB, PHD, biochemist

Golestan Medical School, Jondi Shapour University, Ahwaz, Iran $S$ K IMAM, PHD, assistant professor in clinical biochemistry

\author{
O-DIPHENOLOXIDASE ASSAY
}

O-diphenoloxidase activity was measured using 3,4 dihydroxyphenylalanine (DOPA), tyrosine, and catechol as substrates. The reaction mixture contained $1.0 \mathrm{ml} 0.08 \mathrm{M}$ DOPA, $2.5 \mathrm{ml} 0.01 \mathrm{M}$ phosphate buffer (pH 6.5), and $0.5 \mathrm{ml}$ of affected skin extract prepared by the method of Prabhakaran. ${ }^{1}$ The reaction mixture was incubated at $32^{\circ} \mathrm{C}$ for 15 minutes and then read at $480 \mathrm{~nm}$ on a Bausch and Lomb Spectronic-20 colorimeter.

In the second study catechol was used as the substrate. Enzyme activity was measured by determining the amount of quinone (the oxidised product of catechol) formed as a red coloured compound by reacting with proline. ${ }^{3}$ The colour produced is stable at $\mathrm{pH} 6-7^{4}$ within the range of maximum enzyme activity. The reaction mixture contained $1.0 \mathrm{ml}$ of $0.01 \mathrm{M}$ catechol, $1.0 \mathrm{ml}$ of $0.01 \mathrm{M}$ proline, $1.5 \mathrm{ml}$ of $0.01 \mathrm{M}$ phosphate buffer ( $\mathrm{pH} 6.5$ ), and $1.0 \mathrm{ml}$ of affected skin extract prepared by the method of Prabhakaran.' Substrate solution without enzyme was used as reference. The change in absorption was read at $525 \mathrm{~nm}$ after 90 minutes at $30^{\circ} \mathrm{C}$.

\section{Results}

O-diphenoloxidase level in skin samples-Catechol was oxidised in skin samples from all the patients with lepromatous leprosy (table I). This was shown by the formation of coloured product and confirmed by the absorption spectrum in the visible region, where the absorption maxima was $525 \mathrm{~nm}$. Tyrosine, a specific substrate for mammalian O-diphenoloxidase, was not oxidised by the test solution, indicating that the enzyme was of bacillic origin. Proper controls were included in each experiment to account for the auto-oxidation of the substrate as well as absorbance by the bacilli.

Serum O-diphenoloxidase-Ten of the 15 patients with lepromatous leprosy, who had all had the disease for more than two years, showed considerable enzyme activity with DOPA and catechol as substrates (table II). No catalytic activity with tyrosine could be demonstrated, further confirming that the enzyme was of bacillic origin. In the five patients who had had lepromatous leprosy for less than two years, O-diphenoloxidase was found in skin samples but not in serum. The 15 patients with tuberculoid leprosy also showed no O-diphenoloxidase activity.

\section{Discussion}

Our results show that $\mathrm{O}$-diphenoloxidase activity is not detectable in either normal individuals or in patients with nonlepromatous leprosy. On the other hand, patients suffering from lepromatous leprosy showed significant O-diphenoloxidase activity in both skin and serum.

Leprosy is primarily a disease of the peripheral nerves. In lepromatous leprosy bacilli are spread to the distant nerves and

TABLE I-O-diphenoloxidase estimation in skin biopsies

\begin{tabular}{|c|c|c|c|c|c|c|c|c|}
\hline & & & \multirow{2}{*}{$\begin{array}{l}\text { No of } \\
\text { cases }\end{array}$} & \multirow{2}{*}{ Age and sex } & \multirow{2}{*}{$\begin{array}{l}\text { Duration } \\
\text { of disease } \\
\text { (years) }\end{array}$} & \multirow{2}{*}{ Substrates } & \multicolumn{2}{|c|}{ Increase in optical density at 480 and $525 \mathrm{~nm}^{*}$} \\
\hline & & & & & & & Mean $\perp$ SE & Value of $t$ \\
\hline Normal subjects & . & . & 15 & $20-45 ; 8 \mathrm{M}, 7 \mathrm{~F}$ & & $\begin{array}{l}\text { DL-DOPA } 8 \times 10^{-2} \mathrm{M} \\
\text { Catechol } 0.01 \mathrm{M}\end{array}$ & $\begin{array}{l}0.00 \\
0.00 \\
0.00\end{array}$ & \\
\hline Patients with tuberculoid leprosy & . & . & 15 & $21-48 ; 8 M, 7 F$ & $1-8$ & $\begin{array}{l}\text { Tyrosine } 2 \times 10^{-2} \mathrm{M} \\
\text { DL-DOPA } 8 \times 10^{-2} \mathrm{M} \\
\text { Catechol } 0.01 \mathrm{M}\end{array}$ & $\begin{array}{l}0.00 \\
0.00 \\
0.00\end{array}$ & \\
\hline Patients with lepromatous leprosy & . & . & 15 & $20-45 ; 8 \mathrm{M}, 7 \mathrm{~F}$ & $1-10$ & $\begin{array}{l}\text { Tyrosine } 2 \times 10^{-2} \mathrm{M} \\
\text { DL-DOPA } 8 \times 10^{-2} \mathrm{M} \\
\text { Catechol } 0.01 \mathrm{M} \\
\text { Tyrosine } 2 \times 10^{-2} \mathrm{M}\end{array}$ & $\begin{array}{l}0.00 \\
0 \cdot 161=0.12 \\
0 \cdot 169 \pm 0 \cdot 13 \\
0 \cdot 00\end{array}$ & $\begin{array}{l}0.51<2.1>0.05 ; \text { significant } \\
0.53<2.1>0.05 ; \text { significant }\end{array}$ \\
\hline
\end{tabular}

DOPA $=3,4$ dihydroxyphenylalanine 
TABLE II-O-diphenoloxidase estimation in serum

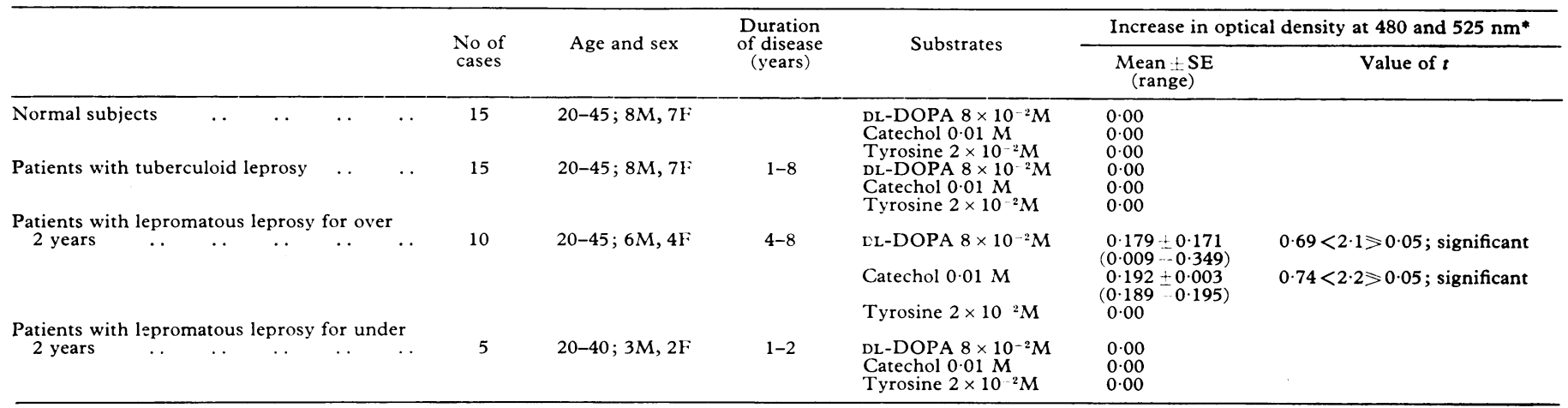

* = Optical density at $480 \mathrm{~nm}$ for DOPA and tyrosine, and $525 \mathrm{~nm}$ for catechol as substrates.

various other organs of the body via blood stream. ${ }^{5}$ Systemic embolisation does not occur in non-lepromatous leprosy, and bacilli are not observed in smears from these patients. It is therefore to be expected that O-diphenoloxidase, which is produced by lepra bacilli, will be detectable in patients with lepromatous leprosy. Further support for the idea that diphenoloxidase is of bacillic origin is provided by the fact that it did not catalyse the oxidation of tyrosine, a specific substrate for mammalian tyrosinase. O-diphenoloxidase is a coppercontaining enzyme, which may explain the hypercuperaemia observed in the serum of leprosy patients.

Estimating O-diphenoloxidase activity may be a useful additional investigation in the diagnosis of lepromatous leprosy. Patients with lepromatous leprosy show less depigmentation than those with tuberculoid leprosy, and this may be due to the increase in diphenoloxidase activity.

\section{References}

${ }^{1}$ Prabhakaran, K, International fournal of Leprosy, 1967, 35, 42.

2 Kuster, E, in Enzyme Chemistry of Phenolic Compounds, ed J B Pridham, p 81.

${ }^{3}$ Mason, H C S, Advances in Enzymology, 1955, 16, 105.

+ Yamaguchi, M, Hwang, P M, and Campbell, J D, Canadian fournal of Biochemistry, 1970, 48, 198.

${ }^{5}$ Jopling, W H, in Textbook of Dermatology, ed A Rook, p 726. Oxford, Blackwell Scientific, 1968.

(Accepted 14 fune 1979)

\section{SHORT REPORTS}

\section{Hyperhidrosis in acromegaly: effectiveness of topical aluminium chloride hexahydrate solution}

Topical $20^{\circ}{ }_{0}$ aluminium chloride hexahydrate solution has been used with success in axillary hyperhidrosis. ${ }^{1}$ Generalised hyperhidrosis is a common symptom in acromegaly." We tried aluminium chloride treatment in four acromegalic patients with particularly troublesome hyperhidrosis to see whether it was effective against sweating associated with excessive secretion of growth hormone.

\section{Patients, methods, and results}

The three women and one man all had active acromegaly with raised growth hormone concentrations not suppressible by glucose load. Two of the women had undergone partial removal of their pituitary tumours followed by external pituitary irradiation. The other two patients were awaiting operation and irradiation. Patients were randomly given identical bottles containing either $20 \%$ aluminium chloride hexahydrate in absolute alcohol or absolute alcohol alone. The $20^{\circ}$, solution was prepared as described, ${ }^{1}$ although using a magnetic stirrer at room temperature caused the aluminium chloride to dissolve in two or three days. Patients were told to apply the solution sparingly at night with cotton-wool to selected areas affected by excessive sweating and to wash off thoroughly next morning (see table). Treatment was applied every night for a week and then as required. After two months they received the second bottle containing the other preparation. The change in severity of sweating was assessed by one of us (IAM) at the end of each two-month period, and the assessment was carried out double-blind.

After the four patients had completed both treatment periods the results were analysed. All reported a great reduction in sweating while using the aluminium chloride solution. All experienced axillary dryness during the day, which was a great social improvement. One patient (case 1) was pleased with cessation of forehead sweating, which had troubled him in bed at night. Three patients (cases 2,3 , and 4 ) received the aluminium chloride solution
Details of patients treated with topical aluminium chloride solution

\begin{tabular}{|c|c|c|c|}
\hline $\begin{array}{l}\text { Case } \\
\text { No }\end{array}$ & Age and sex & $\begin{array}{l}\text { Growth } \\
\text { hormone } \\
(\mathrm{mU} / 1)^{*}\end{array}$ & Areas treated \\
\hline $\begin{array}{l}1 \\
2 \\
3 \\
4\end{array}$ & $\begin{array}{ll}62 & \mathrm{M} \\
42 & \mathrm{~F} \\
58 & \mathrm{~F} \\
59 & \mathrm{~F}\end{array}$ & $\begin{array}{r}200 \\
34 \\
160 \\
36\end{array}$ & $\begin{array}{l}\text { Forehead, axillae } \\
\text { Forehead, axillae, hands } \\
\text { Axillae } \\
\text { Forehead, feet, axillae }\end{array}$ \\
\hline
\end{tabular}

* Mean serum concentration during the day (normal $<10 \mathrm{mU} 1$ ).

first, and when they changed to absolute alcohol alone sweating returned to its previous level within two weeks. The first patient, who started with absolute alcohol, did note some improvement with this but the main improvement occurred with aluminium chloride solution. In all patients maintenance treatment of one or two applications a week controlled symptoms. One patient reported a mild tingling sensation in the treated areas for a few hours after aluminium chloride application.

Bromocriptine treatment was then given to all four patients. In case 4 mean growth hormone concentrations fell significantly on bromocriptine $2.5 \mathrm{mg}$ four times a day, but her severe hyperhidrosis remained. This patient continued to benefit from using the aluminium chloride solution. The remaining three patients all noted a decrease in sweating on bromocriptine but two still preferred to continue with the aluminium chloride solution for complete dryness.

\section{Comment}

Excessive sweating is a common, uncomfortable, and embarrassing feature of acromegaly. Bromocriptine reportedly improves the clinical features of many patients with acromegaly as well as decreases the growth hormone concentrations." Other groups have been less impressed by its therapeutic usefulness in this condition. ${ }^{3}$ We have shown that $20 \%$ aluminium chloride solution can abolish the sweating 